\title{
LA CRISIS DEL ANTIGUO RÉGIMEN DESDE UNA PERSPECTIVA SOCIO-AMBIENTAL. EL CASO DEL REINO DE GRANADA
}

\author{
Manuel González de Molina
}

Tras lo sucedido en este final de siglo, en que los grandes paradigmas interpretativos de la historia han entrado en una irremisible crisis, el abordaje de un tema como el que encabeza este capítulo requiere necesariamente de una revisión crítica, tanto del propio concepto como de su contenido. Ante todo hay que recordar que el concepto "Antiguo Régimen" es una traducción del término acuñado por la historiografía liberal francesa, propensa a sobrevalorar la entidad del cambio ocurrido durante la Revolución. Ambos conceptos nacieron como inseparables en la historiografía contemporánea del país vecino y tuvieron tal éxito en la Europa burguesa del siglo XIX que se convirtieron en una convención utilizada en todas las historiogafía para designar el comienzo de la contemporaneidad. Con el auge del socialismo y más tarde del comunismo, esto es, con el predominio de versiones más o menos ortodoxas del marxismo, los dos términos no hicieron sino reforzar la idea ilustrada que ya había guiado a la burguesía en su afán fundador de una "nueva" sociedad. Tanto para el imaginario teórico y político liberal como para el marxista, la crisis del Antiguo Régimen constituía una prueba evidente de la decrepitud de la sociedad feudal y de la necesidad de la revolución. Ambos conceptos acabaron aplicándose, igualmente, al capitalismo como antiguo régimen en crisis y a la revolución socialista como fundadora de la nueva sociedad que estaba por venir. El mito ilustrado del progreso y de la visión antropocéntrica de la evolución social, que implicaba la posibilidad y aún la necesidad de que el hombre, mediante cambios revolucionarios, acelerase la llegada de estadios superiores de bienestar y perfección material y espiritual ${ }^{1}$, legitimó esta división de la contemporaneidad.

1. Una crítica a los valores de la ilustración y a la teleología tanto marxista como liberal puede verse en G. MARRAMAO, Poder y secularización.Barcelona, 1989; J. BURY, la idea de progreso.Madrid, 1971; F. OVEJERO LUCAS, De la naturaleza a la sociedad. Barcelona, 1987; 
Es por ello por lo que este libro, que aspira a terminar justamente donde empieza la nueva división administrativa que hizo desaparecer el Reino de Granada, se cierra con este capítulo. Pero la denominación de Antiguo Régimen encierra también contenidos que es preciso explicitar, puesto que se dan por sobreentendidos, y que deben ser sometidos a revisión o al menos ser discutidos antes de aplicarlos a la realidad histórica.

En efecto, la oposición entre un Antiguo y un Nuevo Régimen, cuya línea divisoria está establecida por la Revolución, implica, en primer lugar, que ambas sociedades son radicalmente diferentes, con muy pocos rasgos en común. En segundo lugar, que la sociedad del "Antiguo Régimen" es una sociedad atrasada, incapaz de resolver nuevos problemas, de dar cabida a nuevas tareas sociales y a quienes las desempeñan; se asocia, pues, con una sociedad en crisis a la que se considera de manera negativa, en contraste con la consideración positiva, de avance social, de mejora efectiva, que se le concede a la nueva. De hecho, tanto en la teodicea liberal como en la marxista, la sociedad del Antiguo Régimen debe estar en crisis, haciendo depender de esta la inminencia de la revolución: no hay Revolución Liberal sin crisis del Antiguo Régimen; la necesidad de la Revolución es, pues, una condición casi pasiva que depende del grado de crisis en que se encuentra la sociedad feudal. Se comprende así que la historiografía se haya dedicado con afán a la búsqueda de signos de crisis, o que en todos los programas docentes de Historia Contemporánea el tema introductorio sea precisamente la "Crisis del Antiguo Régimen", trasmitiendo al alumno la idea de ruptura y de avance social que significó el régimen liberal establecido por la burguesía y sus aliados. Pero ni la crisis del antiguo Régimen es una necesidad histórica para el cambio social, ni las diferencias entre la nueva y la vieja sociedad son tan marcadas, ni la propia revolución -como veremos- resulta una necesidad derivada de la crisis a la hora de hacer realidad el cambio social, ni este tiene que ser siempre para bien, en una dirección siempre positiva.

En definitiva, la idea de crisis del Antiguo Régimen está íntimamente ligada a la idea de Revolución como vía de cambio y a la Revolución Liberal en específico. La crisis es manifestación de una contradicción insalvable entre el desarrollo de las fuerzas productivas y unas relaciones de producción que las frenan; de ella surgen las fuerzas que hacen posible el cambio revolucionario. Tales fuerzas deben estar compuestas de una clase social en ascenso o grupo de clases que dirigen y protagonizan el cambio revolucionario. La Crisis del Antiguo Régimen es, pues, un período más o menos largo en el que se producen cam-

F. GARRIDO PEÑA, La Ecología Política como política del tiempo. Granada, 1996; un resumen de toda esta crítica a la racionalidad moderna e ilustrada se puede ver, para el caso de la historia, en M. GONZÁLEZ DE MOLINA,"La crisis de modernidad historiográfica y el surgimiento de la historia ecológica", en Culturas y civilizaciones. III Congreso de Historia Contemporánea.Valladolid, 1998, pp. 27-61. 
bios de envergadura que preludian y hacen posible al mismo tiempo la revolución: tales cambios crean y amplían las bases sociales de la clase llamada a protagonizar el proceso, la burguesía.

Sin embargo, conviene hacer algunas matizaciones a este esquema ontológico y, por tanto, demasiado rígido. Los paradigmas tradicionales, especialmente el marxista, tendieron a pensar que el progreso humano exigía cambios en la base de la sociedad que liberaran el enorme potencial que el hombre podía desarrollar mediante el uso de la tecnología. Cuanto más radicales y profundos fuesen esos cambios, más importante sería el salto adelante. Las revoluciones acabaron identificándose con tales cambios sociales. Se esperaba que fuesen radicales, que transformasen en profundidad y casi de repente las relaciones de una sociedad que, pese a estar en crisis, obstaculizaba el progreso humano. Es por ello por lo que la revolución tenía una significación positiva y su realización se consideraba deseable. El resto de los cambios, los que se producían por la propia fuerza de las cosas, por la decisión consciente de los gobiernos o de otros grupos humanos o simplemente por el azar, se les consideraba secundarios e incapaces de generar una auténtica transformación social. El problema residía en que la existencia de un proceso revolucionario acababa midiéndose por la radicalidad del cambio político operado y si éste había traído consigo transformaciones sociales de carácter inmediato. Sin cambio social de envergadura no había existido revolución. Para medirlo se tendió a valorar la entidad de las rupturas y de las continuidades inmediatamente después del proceso revolucionario; ni que decir tiene que el estudio y análisis en profundidad de la sociedad en los momentos finales del Antiguo Régimen desempeñaba un papel crucial. La preponderancia que la nobleza siguió teniendo en Andalucía se consideró, por ejemplo, como indicador de continuidad y del relativo fracaso de la revolución; lo mismo podría decirse de la perviviencia del pequeño labrador o de las práctica clientelares.

La historiografía ha avanzado mucho en este terreno, especialmente tras la caída del Muro de Berlín y la crisis del marxismo y del liberalismo en sus versiones más ortodoxas. Hoy ya no se identifica el cambio social con la revolución, reconociéndose que éste puede venir por diferentes vías; del mismo modo que se reconoce hubo muchos países que accedieron a regímenes liberales y a economías de mercado por métodos no revolucionarios. El debate entre "continuidad o ruptura" carece de sentido no sólo por lo dicho, sino porque en toda sociedad es posible encontrar dosis importantes de cambio y de continuidad sin que ello tenga que afectar necesariamente a su naturaleza. Por último, con el concepto de "Revolución Burguesa" se quería destacar el papel protagonista que la burguesía -de acuerdo con lo sucedido en Inglaterra pero sobre todo en Francia- debía tener en la instauración del régimen liberal y del capitalismo, sistema éste que se suponía hecho a medida de sus intereses. Esta clase debía de haberse formado previamente, durante las décadas finales del Antiguo Régimen, fase en la que de manera cada vez más evidente mostraría sus contradic- 
ciones con la vieja sociedad, adoptando un papel cada vez más activo en el socavamiento de su estabilidad. Dado que, como veremos, la burguesía andaluza del siglo XVIII en nada se parecía a la burguesía francesa protagonista del cambio revolucionario, acomodada como estaba al statu quo, en su debilidad se pretendió fundamentar las propias debilidades del proceso revolucionario andaluz y español, su actitud claudicante ante la nobleza o su acusada tendencia hacia el conservadurismo. Pero no está claro que la abolición del Feudalismo perjudicara a la nobleza o que beneficiara sólo a la burguesía. El nuevo régimen fue implantado gracias a la confluencia de distintos grupos sociales entre los que, efectivamente, estaba la burguesía, o más precisamente, las burguesías andaluzas y españolas. Desprovistos de cualquier teleología metahistórica, de cualquier idea preconcebida en torno a la correcta evolución de la humanidad, hoy tendemos a relativizar el concepto de revolución y a dar protagonismo aa otos grupos sociales no bugueses. Es por ello que creemos más conveniente usar aquí el término de los propios coetáneos para designar la caída del régimen absolutista, "Revolución Liberal", que el más restrictivo de Revolución Burguesa.

Una vez fijadas estas premisas teóricas conviene volver sobre la naturaleza del cambio operado con la Revolución Liberal y por tanto, de la entidad real de la crisis del Antiguo Régimen. Su entendimiento, en los términos en que fue planteado por sus impulsores y no en los términos en que alguna historiografía hubiera querido que se hubiera desarrollado, nos situará en mejores condiciones para entender el alcance de las transformaciones habidas sobre todo durante la primera mitad del siglo XIX. En efecto, el Tardofeudalismo se sustentaba en un ordenamiento jurídico muy específico y en la compulsión extraeconómica o política que hacían posible la extracción del excedente campesino o artesanal y ordenaban las relaciones sociales. Dicho de manera tradicional, los mecanismos político-jurídicos actuaban como "relaciones de producción" y no como parte de la "superestructura". Es lógico pensar que la abolición de dicho entramado acabase de un plumazo con el Feudalismo y que la nueva legislación no hiciera sino sancionar e intentar generalizar unas relaciones sociales basadas en los principios de propiedad privada y prevalencia del mercado. La legislación abría en realidad el camino hacia el definitivo dominio del capitalismo y hacia la subordinación a su lógica de todas aquellas formas de producir y relacionarse distintas, heredadas del pasado. Pero, como veremos, la sociedad granadina del XVIII no estaba mediada únicamente por mecanismos jurídico-políticos; otros mecanismos de asignación de bienes y servicios, como el mercado, tenían una presencia nada despreciable.

En este artículo aceptamos la hipótesis de que, efectivamente, el cambio liberal, operado en España mediante una revolución política, debió ser precedido por un conjunto de fenómenos que podrían agruparse bajo la denominación de "Crisis del Antiguo Régimen". Aceptamos, por tanto, que los cambios habidos en la regulación de las relaciones sociales y en sus formas de organi- 
zación, hundieron probablemente sus raíces en el deterioro de la sociedad preexistente. No obstante, no parece conveniente hacer de la crisis del Antiguo Régimen una precondición revolucionaria con unos contenidos perfectamente establecidos -como se hizo al convertir en modelo lo sucedido desde 1770 en Francia-, sin cuyo concurso podría dudarse del carácter realmente revolucionario de los cambios liberales e incluso de su realización como tales. El cambio liberal no fue algo predeterminado por la propia fuerza de las crisis de la sociedad feudal, ni estaba inscrito en su propia dinámica y evolución como algo inevitable, tal y como la teleología marxista y la propia mitología burguesa insistieron en defender. En consecuencia, debemos preguntarnos ante todo y sin dar por supuesta respuesta alguna, si efectivamente el feudalismo, sistema social con el que se identificaba el Antiguo Régimen, estaba en crisis, al menos en el Reino de Granada, en las décadas inmediatamente anteriores a la Revolución Liberal y, lo que quizá resulta más importante, si esa crisis respondía o no a los supuestos establecidos por la teoría.

Para responder adecuadamente a esta pregunta es preciso analizar, como si de un ejercicio de ecología social se tratara, el estado y el comportamiento de los componentes principales de la sociedad y los fenómenos provocados por su intervención. Vamos, pues, a pasar revista a lo ocurrido en el Reino de Granada durante el siglo XVIII, especialmente en su segunda mitad. No vamos a realizar un recorrido extenso por todos y cada uno de los fenómenos de carácter económico, social y político, puesto que ya se ha hecho en capítulos anteriores y de mano de los mejores especialistas. Aquí sólo vamos a hacer referencia a los procesos que a mi entender, tuvieron una participación decisiva en los cambios y podrían avalar la idea de crisis. No van a tratarse aquí, por la escasez de trabajos específicos sobre el Reino de Granada y la necesidad de un tratamiento más profundo del que aquí podemos dispensar, los cambios operados en las mentalidades y en el pensamiento científico y económico, espcialmente a partir de los ilustrados. Pero antes de entrar en materia, vamos a detenernos un poco en una descripción comprensiva del funcionamiento de la sociedad granadina del setecientos, utilizando para ello la perspectiva que nos proporciona la Historia Ambiental, en la medida en que el conocimiento de las claves de su funcionamiento físico y biológico nos permitirá comprender mejor las necesidades o tendencias al cambio, si es que estas existieron.

\section{Una economía estacionaria}

La sociedad granadina de entonces era una sociedad basada ante todo en las actividades agrarias. Más de las dos terceras partes de la población y un porcentaje similar de la actividad económica se situaba en los campos. La sociedad del XVIII, como ocurría en el resto de Europa, era una sociedad eminentemente campesina, mayoritariamente compuesta de cultivadores directos de la tierra. Este predominio abrumador del sector agrario no era producto de 
la especialización económica; en todo el mundo las actividades productivas se fundamentaban en energías renovables y ello, al nivel tecnológico de entonces, obligaba a obtenerlas mediante la producción de alimentos, el cuidado del ganado o la recolección de combustibles en los bosques. En efecto, el sistema agrario de entonces era esencialmente solar. El ciclo de la materia funcionaba principalmente a través de la energía proveniente del sol. La captación de dicha energía y su conversión a través de la fotosíntesis en alimento o energía sólo era posible mediante el concurso de convertidores biológicos (las plantas) que requerían para ello la ocupación de una cantidad determinada de suelo expuesto a la radiación solar. A diferencia de la agricultura actual, que gracias a los combustibles fósiles puede incluso practicarse sin suelo y en unas condiciones de clima artificialmente creadas, la agricultura tradicional dependía en extremo de las oscilaciones climáticas y, en general, de los condicionamientos de su medio ambiente inmediato. La eficiencia de las plantas útiles en la captación de la energía solar, es decir, el potencial productivo de los agroecosistemas mediterráneos estaba limitado por la pluviosidad y por la cantidad de nutrientes (abono) por unidad de superficie que se pudiera obtener del ganado; lo que es lo mismo que decir que estaba limitado por la cantidad de tierra de que se dispusiera para el alimento humano, el pasto o el cultivo de forrajes. El flujo de energía y de nutrientes era básicamente circular y encontraba sus bases de aprovisionamiento en el área circundante más inmediata. Ello era lógico en un mundo donde los intercambios comerciales eran aún escasos y las comunicaciones muy difíciles, de tal manera que se pudiera conseguir aquello que los terrenos propios no producían con suficiencia. Los campesinos dependían, pues, esencialmente de una explotación racional de los recursos naturales; su subsistencia se basaba más en productos recolectados o cosechados de la naturaleza que en los obtenidos a través del mercado.

En este contexto, el tipo de cultivos y el volumen de las cosechas estaban estrechamente relacionados con los condicionamiento edafoclimáticos, característicos de cada zona geográfica. En el caso del Reino de Granada, los rasgos climáticos más definitorios se encuentran en las fuertes oscilaciones de las temperaturas y en la escasez estructural de las precipitaciones. Las heladas invernales en el interior constituyen una severa limitación a las actividades agrícolas, pero es el segundo rasgo el más generalizado y decisivo. Aunque a finales del siglo XVIII estaba finalizando la llamada Pequeña Edad del Hielo ${ }^{2}$ y debemos suponer que la media de las temperaturas mínimas era más baja que la actual y el volumen de las precipitaciones mayor, las características estructurales de nuestro clima no eran entonces muy diferentes a las de hoy.

2. Vid. F. SÁNCHEZ RODRIGO, Cambio climático natural. La Pequeña Edad de Hielo en Andalucía. Reconstrucción del clima histórico a partir de fuentes documentales. Tesis Doctoral leída en el Departamento de Física Aplicada de la Universidad de Granada, 1994. 
El rasgo agroclimático más acusado, como he dicho, es la escasez e irregular distribución anual e interanual de las precipitaciones. Ello determina la existencia de un período seco más o menos largo que coincide siempre con los meses en que se registran las temperaturas más elevadas del año. El déficit hídrico estival suponía una grave limitación para el desarrollo vegetativo de las plantas (especialmente para los cultivos de primavera-verano), que sólo podía ser parcialmente vencida mediante el recurso al regadío. Derivada de las significativas variaciones interanuales en el nivel de las precipitaciones, existía una segunda limitación importante: la frecuencia de períodos de sequía, con algunos años especialmente secos, y de lluvias torrenciales que a veces provocan inundaciones. Sequía y torrencialidad constituyen dos rasgos propios del clima mediterráneo que ayudan a explicar, siempre en un contexto de agricultura de base orgánica, las más que frecuentes oscilaciones en el rendimiento de las cosechas.

De acuerdo con las limitaciones agroclimáticas descritas, podríamos establecer también la idoneidad de los cultivos. Y ello resulta de interés por cuanto nos puede proporcionar explicaciones bastante ajustadas sobre el predominio de un tipo de cultivos sobre otros, independientemente de que se utilizaran o no en otras monarquías europeas, pretendidamente más avanzadas desde el punto de vista agrícola. Al margen de los cultivos para los que no se tenían condiciones ambientales (cultivos tropicales y subtropicales, salvo las comarcas costeras), las hortalizas, los cítricos, los frutales y plantas industriales -para los que se tenían ventajas comparativas sobre el norte de Europa debido a las condiciones de insolación y temperatura- no podían sembrarse sin el concurso de grandes cantidades de agua que sólo podían venir del establecimiento de nuevos regadíos, algo que entonces estaba sometido a severas limitaciones de carácter tecnológico. La escasez de precipitaciones restringía, por tanto las posibilidades de cultivo a los cereales, a ciertas leguminosas en grano y forrajeras, a cultivos leñosos como la vid, el olivo o el almendro. De hecho, estos cultivos componen la típica trilogía mediterránea que ha caracterizado y aún caracteriza el territorio andaluz.

Dentro de los cereales, el trigo era el preferido al constituir la base de la alimentación humana y alcanzar, por ello, un buen precio en el mercado. Solía sufrir estrés hídrico a partir del mes de abril, justamente en los momentos en que se iniciaba las fases más críticas para el rendimiento floral (floración y llenado del grano). De ahí que, como han demostrado los balances hídricos que hemos realizado en otro lugar ${ }^{3}$, el rendimiento usual estuviera en torno al $60 \%$ del que se obtendría de no existir limitación hídrica. Aunque proporcionaba precios menores, la cebada constituía un cultivo indispensable para la alimentación del

3. J. CARLOS AVILA y M. GONZÁLEZ DE MOLINA, "El agua como factor limitante de la producción agrícola en Andalucía Oriental. La Vega de Granada, siglos XIX y XX", enR. GARRABOU y J.M. NAREDO (eds.), El agua en los sistemas agrarios. Una perspectiva histórica. Madrid, 1999, pp. 275-316. 
ganado de labor. Avena o centeno cumplían parecidas funciones. En cuanto a las leguminosas, ocupaban el suelo durante el invierno debido a la sequía estival, lo que les hacía incompatible con los cereales en el mismo año agrícola. Pero aún hay más. Las específicas condiciones climáticas imponían fuertes limitaciones a la producción de biomasa por hectárea, fuese esta cultivada, fuesen pastos o materia forestal. Ello traía aparejada otras consecuencias negativas que no se agotan en el mero rendimiento físico de una finca sembrada de trigo por ejemplo. Para que la cosecha en esa finca fuese exitosa, se requería la utilización subsidiaria de otras parcelas o fincas equivalentes en superficie dedicadas al descanso (barbecho), a la producción de forrajes para alimentar al ganado de labor y renta, a la producción de combustibles vegetales para calefacción y comida de las familias y, por tanto, de los trabajadores que empleaban su energía en el cultivo de la mencionada finca.

En definitiva, la duración del período seco y las altas temperaturas, creaban condiciones ecológicas hostiles para la actividad agrícola. El cultivo debía ser preferentemente de invierno $y$, en todo caso, de primavera-verano, aprovechando para el crecimiento de las plantas las lluvias de primavera. Los segundos frutos estaban, pues, descartados o reducidos a algunas zonas privilegiadas junto a los ríos o cursos de agua. La alta insolación y la escasez de lluvias reducían la materia orgánica del suelo por lo que era prácticamente imposible cultivar un año tras otro en la misma parcela sin utilizar cantidades importantes de estiércol, fertilizante éste que escaseaba debido al menguado tamaño de las cabaña ganadera, lo que a su vez estaba en función de la escasa oferta de alimentos que ofrecían los pastos gracias a las precipitaciones. Ello obligaba a realizar rotaciones en las que después de un año de cosecha debía suceder un año de descanso y otro de barbecho o preparación para el siguiente año de cultivo (rotación al tercio), es decir a recuperar los nutrientes extraídos por la planta en el año de cultivo. En estas condiciones de baja productividad de biomasa, la capacidad de mantener una cabaña ganadera abundante y de producir más materia fertilizante estaban también limitadas: el monte mediterráneo e incluso el adehesado no podían compararse con los prados de la Europa Húmeda, debiendo competir por el suelo con los cultivos destinados a la alimentación humana. Era una especie de círculo vicioso. Sólo en los ruedos de los pueblos se conseguían cultivos anuales, combinando cereales con leguminosas gracias a la utilización del estiércol y los residuos urbanos; pero este sistema de ruedos distaba mucho de poder generalizarse. La única manera de mantener cultivos anuales, sin descanso residía en las plantas arbustivas o arbóreas, especialmente el olivo, la vid y el almendro.

En otras palabras, la agricultura de mediados del siglo XVIII estaba sometida a una limitación ecológica fundamental: dadas sus carencias en humedad y nutrientes, necesitaba dedicar más cantidad de tierra a las actividades agrarias que los países del norte de Europa para producir la misma cantidad de producto. Ello hacía en buena medida incompatible el uso agrícola con el pecuario o 
forestal en la misma parcela de tierra. Por ejemplo, para obtener la misma cantidad de trigo que se obtenía por hectárea en el condado de Norfolk, allí donde nació la llamada "Revolución Agrícola", se necesitaban cuatro en la actual provincia de Granada de media, según hemos podido calcular en un reciente trabajo ${ }^{4}$. Durante esos años y los que vendrían después hasta finales del siglo XIX, la abundancia relativa de tierras evitaron que este fenómeno llegase a constituir un fenómeno grave o que provocase una fuerte emigración. En cualquier caso, no puede decirse de ninguna manera que la agricultura del Reino de Granada fuese una agricultura estancada o ineficiente por el simple hecho de tener mucha tierra "inculta" (es decir, dedicada a otras funciones agrarias imprescindibles) o proliferara el barbecho (práctica agronómica absolutamente necesaria en ausencia de fertilizantes químicos) ${ }^{5}$.

Consecuentemente con los dicho, cada núcleo de población organizaba su espacio circundante de tal manera que pudiera, de acuerdo con sus específicas condiciones ambientales, disponer de tierra cultivada suficiente para alimentar a sus vecinos, pero también del suficiente pasto para alimentar a los animales que realizaban el trabajo duro del campo o transportaban los enseres, e incluso complementaban ocasionalmente la alimentación humana, y de los suficientes bosques para disponer de combustible y materiales de construcción como para sostener no sólo el consumo doméstico de energía sino la requerida para las actividades artesanales y, en su caso, navales. Aunque no todos los pueblos poseían una dotación de recursos suficientes como para mantener el equilibrio entre las necesidades alimentarias, pecuarias y energéticas, todas las comunidades rurales se veían obligadas a procurarlo.

\section{La organización social de la producción}

La estabilidad de este tipo de economía de base energética orgánica ${ }^{6}$ dependía, como hemos dicho anteriormente, del equilibrio cambiante entre necesidades endosomáticas y exosomáticas, entre la producción de alimentos, forrajes y combustibles. Dadas las limitaciones energéticas de este tipo de economía y los "bajos rendimientos" que, a pesar de los esfuerzos de fertilización, se podían conseguir, es lógico que el manejo directo de todo este sistema, su clave, correspondiera a un tipo de cultivador que dispusiera en abundancia de la fuerza de trabajo y del conocimiento suficiente sobre los ciclos naturales y agríco-

4. M. GONZÁLEZ DE MOLINA, "The Limits of Agricultural Growth in Nineteenth Century. A Case Study form Mediterranean World", en International Conference: Nature, Society and History. Long Term Dynamics of Social Metabolism. Viena, septiembre de 1999 (en prensa).

5. Esto puede comprobarse a través de los balances de nutrientes que hemos realizado en M. GONZÁLEZ DE MOLINA y Y. POULIQUEN, "De la agricultura orgánica tradicional a la agricultura industrial: )Una necesidad ecológica?, en R. GARRABOU y J.M. NAREDO (eds.), La fertilización en los sistemas agrarios. Una perspectiva histórica. Madrid, 1996, pp. 127-170.

6. El concepto se debe a E.A. WRIGLEY, Continuidad, cambio y azar. Barcelona, 1993. 
las -aunque fuera experimentalmente aprendido-; que no buscara tanto la maximización de sus oportunidades de consumo o beneficios como la procura de la subsistencia, limitando su capacidad de consumo a aquella dotación de trabajo que fuese capaz de emplear él mismo y su familia (recuérdese que la producción de alimentos estaba físicamente limitada por la imposibilidad material de añadir grandes cantidades de energía y materiales de fuera del sistema agrario); que se mantuviese al frente de la explotación con una mentalidad a largo plazo, autoexplotándose si era necesario o consumiendo menos de lo imprescindible para capear las situaciones difíciles que imponía la coyuntura ambiental, política o económica; en definitiva, que procurase maximizar el producto bruto de la explotación sin esquilmar la tierra en la medida en que de ello dependía su autosuficiencia, su subsistencia.

Pero el grupo doméstico campesino sólo podía manejar un trozo de agroecosistema. El manejo y control del conjunto resultaba imprescindible para la sobrevivencia de la explotación, cuestión esta que correspondía a la comunidad campesina. Efectivamente, las comunidades locales poseían, en tanto que núcleos básicos de organización de la sociedad rural, amplias competencias sobre todos los factores productivos. Poseían grandes cantidades del factor decisivo, la tierra, en propiedad o en administración (propios y comunales) y regulaban el funcionamiento de muchos aspectos de la producción. Constituían, pues, instrumentos esenciales en la reproducción del carácter orgánico de la economía y, por tanto, en la preservación de la estabilidad o en la generación de la crisis. En este sentido, tendemos a pensar que la existencia y promoción de los bienes y derechos comunales no era sino una forma de asegurar en el largo plazo las funciones alimentarias, energéticas, de beneficencia, agrarias, etc. que estas reservas de tierra y de aprovechamientos desempeñaban para la reproducción de la comunidad y para la sostenibilidad de la producción agrícola; comunales que surgen y se consolidan a partir de la existencia de un peligro real de apropiación agrícola o privada, causada bien por la ambición de los señores feudales, de las élites locales o de las necesidades creadas por el propio crecimiento de la producción. En el caso andaluz, los bienes comunales desempeñaron un papel esencial no sólo en la preservación de una cabaña ganadera más o menos suficiente y por tanto en la satisfacción de las necesidades e fertilización y tracción de las explotaciones agrarias, sino que constituyeron auténticas instituciones de beneficencia que sirvieron de colchón contra la pobreza a los grupos sociales más desfavorecidos de cada comunidad: podían obtener del monte los combustibles, parte de los alimentos e incluso una parte de los ingresos que el trabajo estacional en las grandes o pequeñas explotaciones agrícolas provocaba. Andando el tiempo, la desarticulación de los bienes y derechos comunales, operada con la penetración de la propiedad privada, desempeñaría un papel determinante no sólo en la disolución de la comunidad campesina sino también en la propia disolución del campesinado como tal. 
Pero de todo este mundo agrario, la gran fuente de riqueza del siglo XVIII, obvio es decir que no todos participaban por igual. Muy al contrario, las diferencias eran importantes, pero menores de las que resultarían de las reformas liberales y de la consolidación de la propiedad privada. La propiedad de la tierra se estructuraba, aparentemente, de forma muy polarizada, con grandes diferencias según los grupos sociales de que hablemos. Pero debe tenerse en cuenta que existía una cantidad considerable de tierra de carácter comunal en la que el aprovechamiento (pastos, combustibles, materiales de construcción, alimentos y caza silvestre, plantas medicinales y otras materias primas) era gratuito para todos los vecinos y que el concepto de propiedad privada como disfrute absoluto y excluyente no se había instituido aún en las tierras cultivadas. Estas soportaban a menudo servidumbres y derechos a favor de la comunidad vecinal, tales como la derrota de mieses, el espigueo, la rebusca, etc. La apropiación privada de un predio se entendía como el dominio del mismo, es decir como el derecho a cultivarlo y a recolectar la cosecha o bien a percibir una renta por cederlo a terceros ${ }^{7}$.

En efecto, la agricultura del Reino de Granada en la segunda mitad del siglo XVIII estaba organizada en torno a un conjunto tipológicamente heterogéneo de comunidades campesinas, en el seno de las cuales se habían establecido con el tiempo importantes desigualdades sociales. Desde el punto de vista de la propiedad, su mayor o menor grado de desigualdad dependía de la incidencia que en su seno tuvieran los grandes patrimonios rústicos de la nobleza, la Iglesia o la pequeña propiedad ${ }^{8}$. Pero desde el punto de vista del cultivo, parece probado el predominio de la explotación campesina, basada en el trabajo familiar y orientada hacia la subsistencia, como el elemento numéricamente dominante. La gran explotación coexistía con una extensión superficial y una importancia económica relevante, Ilevada por grandes arrendatarios que utilizaban mano de obra asalariada. Pero esta específica relación basada en el salario no constituía la forma única ni la más generalizada. Al contrario de lo que ocurría en la Depresión del Gudalquivir, sólo el 7\% de la extensión superficial que controlaban los mayores hacendados en toda Andalucía se asentaba en el Reino de Granada9. Muchos de los latifundios existentes en el Reino de Granada se fragmentaban, además, en pequeñas suertes cedidas en arrendamiento o subarrendamiento. El predominio de la pequeña explotación era, en medio de una estructura de la propiedad bas-

7. Vid las interesantes reflexiones al respecto contenidas en C. ÁLVAREZ ALONSO, "Las dos caras de Jano. Propiedad y constitución en el primer liberalismo español", en S. DE DIOS et allii, Historia de la propiedad en España. Madrid, 1999, pp. 297-327.

8. Hemos desarrollado este extremo en M. GONZÁLEZ DE MOLINA y E. SEVILLA GUZMÁN, "Minifundio y gran propiedad agraria: estabilidad y cambio en la Alta Andalucía, 1758-1930", en P. SAAVEDRA y R. VILLARES (EDS.), Señores y campesinos en la Península lbérica, siglos XVIII-XX. Barcelona, 1991, pp.88-138. Véase también lo dicho en el capítulo 9 de este volumen.

9. M. ARTOLA et allii, Latifundio. Madrid, 1978, capítulo I, cuadro 13 y pp.44-48. 
tante polarizada, posible gracias al arrendamiento como forma de tenencia: según el censo de 1799, existía el mismo porcentaje de colonos que propietarios de la tierra. ${ }^{10} \mathrm{Y}$ esto, como veremos, tiene bastante importancia a la hora de explicar la incapacidad del Antiguo Régimen para asegurar el abastecimiento alimentario. Ello explica, también, que un porcentaje elevado de la población tuviera un acceso directo al cultivo de la tierra" ${ }^{11}$

Según ha escrito recientemente Enrique Soria ${ }^{12}$, el Feudalismo no había sido aquí nunca como en otras zonas del norte peninsular y europeo, dada su tardía implantación. Aunque la sociedad se asentaba sobre la clásica división estamental: nobleza, clero y estado llano y el privilegio y la desigualdad regían la adscripción social de los individuos, la fuerza de tales formas de organización social había disminuido significativamente. Las diferencias sociales en función del dinero y de la posesión de la tierra, o bienes inmobiliarios, tenía ya bastante relevancia social, de tal manera que el patrimonio y las posibilidades de acceder a él, de conseguirlo y acrecentarlo, constituían los medios más rápidos y seguros de movilidad social, al margen de la pertenencia estamental o la cuna. Ello se evidencia, por ejemplo, en las diferencias sociales que albergaban los estamentos del clero y la nobleza: poco tenía en común el arzobispo de Granada con un párroco de la Alpujarra, del mismo modo que el Marqués del Zenete con cualquier hidalgo. Nada que argumentar respecto al tercer estado, definido por oposición a los otros dos, que encubría una multiplicidad de situaciones sociales. Al margen, pues, de la división estamental, podemos vislumbrar una sociedad polarizada entre ricos y pobres, entre por un lado la nobleza terrateniente, las altas jerarquías de la Iglesia granadina y los ricos comerciantes y labradores, algunos de ellos elevados a la categoría nobiliaria por gracias reales o, más frecuentemente, por compra de títulos. En definitiva, la promoción social estaba ya bastante ligada con la entidad del patrimonio y este irremisiblemente ligado a las escasas oportunidades que ofrecía el mercado de bienes inmobiliarios en medio de un ordenamiento jurídico dominado por el régimen de amortización.

No obstante, conviene que nos detengamos en la configuración concreta del Régimen Señorial. Ello resulta básico para entender los motivos de la crisis del Antiguo Régimen y la "sorprendente" actitud de una parte significativa de la nobleza terrateniente a favor del Cambio Liberal. De nuevo Enrique Soria nos servirá de guía, esta vez a partir de su tesis doctoral sobre los señoríos en el Rei-

10. A. M. BERNAL, Historia de Andalucía. Barcelona, 1981, volumen VII

11. Manuel Martínez Martín ha calculado que más de la mitad de los vecinos de Santa Fe tenían acceso a la tierra mediante propiedad o, más frecuentemente, en arrendamiento, habida cuenta que la mayoría delos propietarios de la tiera eran forasteros o "manos muertas". Vid. M. MARTÍNEZ MARTÍN, Revolución Liberal y cambio agrario en la Alta Andalucía. GRanada, 1996.

12. E, SORIA MESA, "Los orígenes de la contemporaneidad: Andalucía en el siglo XVII", en M. GONZÁlEZ DE MOLINA y M.GÓMEZ OLIVER (Coords.), Historia de Andalucía Contemporánea. Nuevos contenidos para su estudio. Granada, 2000, capítulo 11. 
no de Granada ${ }^{13}$. Según los datos que aporta, extraídos del Catastro del Marqués de la Ensenada, casi el 30\% de la población granadina estaba sujeta a jurisdicción señorial. Porcentaje relativamente importante que había ido creciendo desde la expulsión de los moriscos gracias al incremento del números de pueblos sometidos a jurisdicción por enajenaciones de la Corona y por la inmigración constante que habían producido las mejores condiciones que regían en los señoríos respecto al realengo. Si se descuenta la población que residía en las ciudades, se puede llegar fácilmente a la conclusión de que prácticamente la mitad de la población rural estaba sometida a jurisdicción señorial. Lo cual no quiere decir que este se econtrase en sus mejores momentos.

Uno de los elementos fundamentales para valorar la incidencia del Cambio Liberal, para valorar la actitud de la nobleza y, en definitiva, para proceder a un diagnóstico más o menos ajustado de la crisis del Antiguo Régimen ha sido siempre el conocimiento de lo que la nobleza se jugaba con la supresión del Régimen Señorial. El conocimiento de la naturaleza y entidad de los derechos y en general de las rentas que percibían los titulares de señorío, ha resultado decisivo. Este aspecto concreto ha estado, y no por casualidad, en el centro de las controversias historiográficas, desde la aparición de los libros de García Ormaechea y de Salvador de Moxó hasta los últimos trabajos de Pedro Ruiz Torres, al que nos referiremos más adelante. Según E. Soria, el grueso de las rentas señoriales estaba compuesto por las "tercias"y en menor medida por las "alcabalas". Ambas habían sido enajenadas por la Corona. Los derechos propiamente jurisdiccionales apenas si tenían importancia: "Bajo esta denominación [rentas jurisdiccionales] se engloban diferentes rentas señoriales que emanan de la posesión de la jurisdicción. Son bien distintas, unas referidas al reconocimiento de vasallaje, otras a la administración de justicia y del derecho señorial establecer monopolios; algunas cuantas derivadas del nombramiento de oficios municipales... su rendimiento era ínfimo"14.

Tampoco eran muy importantes las rentas percibidas por la cesión de propiedades territoriales propias del señorío. Lo normal era que un puñado de grandes propietarios locales poseyera mucha más tierra que sus señores. Las propiedades de la nobleza en sus señoríos no eran numerosas ni muy extensas

13. E. SORIA MESA, Señores y oligarcas: los señoríos del Reino de Granada en la Edad Moderna. Granada, 1997.

14. Ibidem, p. 140. La tesis de L.C NAVARRO (Transformaciones agrarias liberales en Andalucía Oriental: Almería, siglos XVIII-XIX. Granada, 1999, p. 102) confirma esos extremos para la provincia de Almería: "De hecho, los análisis de las contabilidades de las casas nobiliarias que se han estudiado, demuestran palpablemente que los ingresos derivados de los derechos estrictamente jurisdiccionales son una parte muy pequeña en relación con las rentas e ingresos procedentes de las propiedades, y al mismo tiempo ponen de manifiesto la activa política de compras de patrimonios tanto dentro como fuera del señorío, junto a otras estrategias en el engrandecimiento de las Casas, que confieren un extraordinario poder a las principales líneas de la nobleza asentadas en Andalucía..." 
y proporcionaban un porcentaje bastante reducido del conjunto de los ingresos señoriales. Ello no quiere decir que la nobleza careciera de bienes. Todo lo contrario, poseían extensos patrimonios inmobiliarios, especialmente rústicos, sometidos a vinculación o amayorazgamiento, pero situados fuera de sus dominios jurisdiccionales, especialmente en poblaciones de realengo. Las conclusiones de esta específica configuración del régimen señorial granadino las resume el propio Soria: "En cualquier caso, lo que interesa poner de relieve ahora es un fenómeno de gran trascendencia, no excesivamente destacado por la reciente historiografía: la importancia en el conjunto de la hacienda nobiliaria de esta renta de la tierra que nada tiene que ver con el hecho señorial. En muchos casos, y hablo del Reino de Granada, la mayoría de los ingresos de las casas nobles proceden de estas grandes propiedades en realengo, relegando a un puesto secundario a las rentas estrictamente señoriales". ${ }^{15}$

"La preocupación de los grandes patrimonios, en los siglos XVIII y XIX, consiste -añade Enrique Soria ${ }^{16}$ - en preservar sus bienes territoriales, incrementar y redondear su patrimonio, fundamentalmente mediante compras, y asegurar el control de la población jornalera y/o colona que lo trabaja". Y este aspecto resulta fundamental. Contribuye a explicar la actitud de la nobleza granadina en el momento de la disolución del régimen señorial, más preocupada por la conservación y acrecentamiento de su patrimonio rústicos, y por tanto interesada en la "liberalización" del mercado de tierras, que en el mantenimiento de las rentas señoriales, algunas de las cuales habían sido incluso enajenadas a "oligarcas locales", por supuesto no titulados. La recaudación de las alcabalas se había estancado hacía mucho tiempo y las tercias eran cada vez más difíciles de cobrar, sobre todo desde el momento en que los primeros cambios liberales crearon expectativas fundadas sobre la pronta desaparición del diezmo. En cualquier caso, y como ha explicado Ricardo Robledo ${ }^{17}$, el nuevo Estado liberal se encargó de indemnizar a los partícipes laicos del diezmo con títulos de la deuda pública que pudieron utilizar en la compra de bienes nacionales. Se explica así, el amplio respaldo social con el que contó la supresión del régimen de amortización, tanto por parte de los hacendados locales contrarios al mantenimiento del régimen señorial y la vinculación como de los señores, interesados en mantener y ampliar sus patrimonios. Sólo aquella parte de la nobleza que se había endeudado y que se amparaba en la "irresponsabilidad patrimonial"18, estaba interesada en el mantenimiento del régimen de amortización.

15. Ibidem, p.145

16. Ibidem, p.146.

17. R. ROBLEDO HERNÁNDEZ, “Desamortización y Hacienda Pública en algunos inventarios de grandes terratenientes", en A. GARCÍA SANZ y R. GARRABOU, Historia agraria de la España Contemporánea. Barcelona, 1985,vol. I, pp. 395-432.

18. Sobre este concepto véase B. CLAVERO SALVADOR, Mayorazgo. Propiedad feudal en Castilla. Madrid, 1974. 
Tanto David Martínez López ${ }^{19}$ como el propio Enrique Soria han descrito cómo se produjo el ascenso social de un grupo importante de grandes propietarios de tierras y oficios, amparándose en la necesidad que los grandes propietarios nobles o forasteros tenían de arrendar sus propiedades rústicas, dispersas por todo el Reino y en la utilización de los resortes del poder local. Todo ello combinado con estrategias matrimoniales exitosas y la utilización de las ventajas que el vínculo e incluso el mayorazgo ofreció hasta un cierto momento para la consolidación de sus patrimonios y de su ascenso social. Y fue una parte de estas "élites" locales las que protagonizaron el grueso de la lucha antiseñorial, no en contra de pesadas rentas sino por el control de los ayuntamientos y demás resortes del poder político local, imprescindible para asegurar la reproducción viable de las explotaciones agrarias y el manejo adecuado a sus intereses de los recursos naturales propios de la comunidad ${ }^{20}$. No hubo aquí, como en Francia o en otros lugares de la península una lucha antiseñorial protagonizada por campesinos y propietarios no nobles contra las rentas señoriales que pusiera en cuestión el señorío mismo y, con él, el régimen feudal en su conjunto. Fueron las posibilidades de controlar los poderes locales, derivadas de la propia jurisdicción, las que centraron la lucha antiseñorial. Pero, como han demostrado tanto Margarita Ortega ${ }^{21}$ como Antonio Luis Cortés Peña ${ }^{22}$, los conflictos más frecuentes no fueron estos, sino aquellos que enfrentaron a los grandes propietarios de la tierra, nobles o no, y los labradores que la cultivaban en régimen de arrendamiento; a los vecinos con sus concejos por el aprovechamiento comunal o los impuestos; a los concejos entre sí por el usufructo de tierras comunales en litigio. Como dice este último autor, las causas de la mayoría de los conflictos eran debidas a problemas con las lindes, asentamientos, roturaciones, talas, pastos, etc..., sin olvidar las frecuentes disputas entre agricultores y ganaderos; conflictos distributivos que no afectaban directamente al régimen señorial y que siguieron existiendo a lo largo del siglo XIX.

\section{Factores de inestabilidad y crisis}

En una economía estacionaria y en un tipo de sociedad como la que hemos descrito, existían factores de inestabilidad que podían desequilibrarla y provo-

19. D. MARTÍNEZ LÓPEZ, Tierra, herencia y matrimonio, un modelo sobre la formación de la burguesía andaluza (siglos XVIII-XIX). Jaén, 1996.

20. He desarrollado este aspecto, referido a la importancia que tuvo el control de los poderes locales para el mantenimiento del equilibrio agrosilvopastoril y para la regulación del disfrute de los bienes y derechos comunales en M. GONZÁLEZ DE MOLINA,"La funcionalidad de los poderes locales en una economía orgánica", en Noticiario de Historia Agraria, no 6, 1993, pp. 9-23.

21. M. ORTEGA, La lucha por la tierra en la Corona de Castilla. Madrid, 1986.

22. A.L. CORTÉS PEÑA, "Tensiones campesinas en la Andalucía Moderna", en M. GONZÁLEZ DE MOLINA (ed.), Campesinos y jornaleros. Una revisión historiográfica. Barcelona, en prensa en la editorial Anthropos. 
car su crisis, que no su caída, cosa bastante diferente. Tales factores podían surgir tanto del interior de la propia sociedad como del exterior. Vamos a describir brevemente los principales. Pero antes es preciso dejar claro que una economía estacionaria es una economía en la que por definición es imposible que tengan lugar procesos generalizados de crecimiento económico; es decir, es una economía que crece, en el mejor de los casos, al mismo ritmo que la población. Ahora bien, tal "crecimiento" no puede mantenerse indefinidamente ya que choca con límites ambientales e institucionales. Por ejemplo, en el caso de un incremento de la población, las roturaciones no podrían absorber de manera indefinida las necesidades alimentarias de los nuevos individuos al encontrarse con tierras sin vocación agrícola para roturar o sometidas a un régimen jurídico -por ejemplo el comunal-que lo impidiera. Habría, pues, un punto máximo a partir del cual las roturaciones acabarían rompiendo el equilibrio agrosilvopastoril. En otros términos, a partir de un determinado momento en que la población comenzó a crecer de manera continuada, el Antiguo Régimen debió mostrar una creciente incapacidad para alimentar, mediante el crecimiento del volumen de la producción agraria, al crecimiento demográfico, una vez que la población comenzó a romper los frenos que suponían las altas tasas de mortalidad y la mortalidad catastrófica. Mientras los predadores naturales del hombre durante la época preindustrial (es decir, bacterias y virus de enfermedades como el cólera, la peste, la gripe, las tercianas, etc...) mantuvieron el crecimiento de la población en niveles muy bajos, el régimen feudal pudo absorber la mayor demanda de alimentos y combustibles, e incluso pudo primar la ganadería para la exportación, en perjuicio de la agricultura como ocurrió en la Corona de Castilla, concediendo privilegios a la Mesta.

La capacidad de sustentación, es decir, la cantidad máxima de población que un determinado ecosistema puede alimentar sin degradar la base de sus recursos y sin cambiar las formas sociales e institucionales de su manejo, depende de varios factores. En un esfuerzo de simplificación podríamos corregir la ecuación de Paul Erlich para dar cabida a planteamientos de carácter social, que afectan a la manera en que se distribuye la producción entre los distintos individuos de una sociedad ya que alteran, algunas veces sustancialmente, la propia capacidad de sustentación. Según Erlich, la capacidad de sustentación de un ecosistema depende del volumen de la población, de los flujos externos que recibe en formas de subsidios de energía o materiales y del nivel de eficiencia en el uso de los recursos naturales, nivel este que está determinado por el grado de sofisticación de la tecnología utilizada. Está claro, sin embargo, que una distribución del producto alimentario que sea desigual ente los distintos individuos, puede disminuir la capacidad de carga de un ecosistema y de la sociedad que sobre él se sustenta.

Aplicando esta metodología corregida a la economía y al entramado social del Antiguo Régimen, podríamos decir que una determinada sociedad, en este caso el Reino de Granada, tendría problemas serios para sostener a su pobla- 
ción sin producir cambios sociopolíticos de envergadura cuando se dieran algunas de los siguientes factores, bien sólos o en combinación; todo ello en el entendimiento de que, como vamos a ver, la tecnología disponible no permitía incrementos sustanciales y constantes del nivel de la producción, especialmente en el sector agrario. En primer lugar, el mencionado equilibrio podría romperse por un aumento de la población que requiriera un incremento de la superficie cultivada para atender a las nuevas necesidades alimentarias, pero al mismo tiempo de la superficie forestal para atender a sus necesidades energéticas (cocina, calefacción, etc.), cuestiones ambas teóricamente incompatibles en el seno de un sistema productivo en el que el incremento de los rendimientos por unidad de superficie era muy difícil. La presión hacia el uso agrícola del territorio podía verse estimulada por un aumento del consumo en uno o varios grupos sociales o simultáneamente por los intentos de subvenir unas necesidades deficitarias en granos básicos, por ejemplo, o de mejorar el consumo. Obviamente, las presiones hacia la ruptura del equilibrio agrosilvopastoril podrían venir del efecto conjunto tanto de la elevación del consumo como del aumento del número de consumidores.

En segundo lugar, la rotura del equilibrio podía ser resultado de una mala distribución de la propiedad y de la explotación de la tierra y de las rentas que esta generaba. Parece claro que una estructura de la propiedad y de las explotaciones muy desequilibrada, en la que la mayor parte de la población careciera o estuviera excluida del disfrute de la tierra o de sus productos, podría provocar una situación en la que los más pobres pretendieran roturar la tierra o sobreexplotar los recursos comunales para poder sobrevivir. De la misma manera, los más acaudalados podrían intentar apoderarse de tierras comunales o de dudosa propiedad para incrementar sus patrimonios. En otros términos, una mala distribución del producto y de la renta agraria podrían intensificar la sensación de insuficiencia, e incluso de privación de la tierra, al permanecer un sector muy importante excluido de su disfrute. Es más, esa escasez real de alimentos básicos (granos sobre todo y en especial trigo), que presionara hacia un incremento de la superficie cultivada, por ejemplo, podría verse aumentada por la actitud acaparadora o simplemente mercantil de comerciantes y grandes perceptores de rentas, al preferir la venta en mercados más rentables (América por ejemplo) que el consumo in situ; ello intensificaría, por ejemplo, el desabastecimiento y reduciría dramáticamente la autosuficiencia alimentaria, exigiendo la entrada del exterior de nuevos contingentes de alimentos y una mejora de las comunicaciones y la eliminación de las trabas al comercio que la hiciera posible.

En tercer lugar, el equilibrio podías verse seriamente dañado si, por las circunstancias que fueren (especialmente, un aumento de la demanda externa de productos manufacturados) tuviese lugar un crecimiento de la actividad industrial o manufacturera que excediera las posibilidades de proporcionar combustibles de las zonas forestales circundantes, requiriera gran cantidad de mano de obra o de una red comercial amplia para dar salida a los productos elaborados. 
El caso de la industria azucarera motrileña puede servir de ejemplo, en crisis no sólo debido a la competencia del azúcar caribeño, sino también a la falta estructural de fertilizantes para incrementar la producción y los rendimientos y de combustibles para mantener y ampliar la potencia instalada ${ }^{23}$. Con una estructura de comunicaciones y regulaciones mercantiles bastante desfavorables, incluso en la misma periferia, estos procesos industriales sólo podían ser viables si se modificaba el marco jurídico y tributario que regulaba las relaciones comerciales y si estas se ampliaban considerablemente.

En cuarto lugar y paradójicamente, el equilibrio podía quedar roto también por el auge de las actividades comerciales, ya fuera para abastecimiento externo o ya fuese para la exportación. En la medida que el mercado de entonces era el lugar en el que se conseguía la energía y los materiales que faltaban o viceversa, podía trasladar al interior del Reino de Granada, vía precios relativos y pese a la "imperfección" de los mercados de entonces, presiones existentes en otras zonas para la producción de más granos básicos, más carbón vegetal, más cultivos industriales, etc. por encima de la demanda local. El efecto sería un incremento considerable de la presión agrícola sobre el territorio y, sobre todo, una tendencia a la especialización que, a la larga, reforzaría la dependencia de unas zonas respecto a otras a través del mercado. El caso de las zonas costeras de la provincia de Málaga resulta paradigmático: la especialización vitícola provocada por la cercanía del puerto habilitado para el comercio colonial, obligó a importaciones frecuentes de granos básicos que había dejado de sembrarse para aprovechar las nuevas oportunidades del mercado, del cual se hicieron más dependientes ${ }^{24}$. El resultado, en cualquier caso, del auge de las relaciones comerciales sería la expansión mayor de las mismas y una creciente dependencia de ellas de la sociedad, lo que a su vez agravaría el desequilibrio. En cualquier caso, la aparición de productos básicos en cantidad suficiente y de otros nuevos aumentaría la propensión a comprar y excitaría el apetito de los grupos rentistas por recaudar más y aumentar en lo posible sus rentas y derechos señoriales.

A ello debería añadirse la presión fiscal del Estado, embarcado en guerras y otras "empresas" imperiales e incluso el propio proceso centralizador de la Monarquía Absoluta que, al requerir mayores recursos, presionaría sobre las clases y grupos no privilegiados para que pagaran más impuestos. Y este cuarto aspecto tiene mucho que ver con la visión tradicional que el cierto mar-

23. Vid. J.L. CASTELLANO CASTELLANO, El siglo de las luces. Agricultura y sociedad motrileña. Motril, 1997.

24. Aunque parece que la especialización vitícola tuvo que ver también con la importación, a partir de la mitad del siglo, de granos a bajo precio. Vid. A. GÁMEZ AMIÁN, "Aproximación al influjo del libre comercio con América en la economía de Andalucía Oriental", en J. FONTANA y OTROS, El comercio libre entre España y América Latina, 1765-1824. Madrid, 1987, pp. 123-143. 
xismo ortodoxo ${ }^{25}$ defendió: la crisis del régimen feudal en la práctica habría sido el resultado de la lucha de clases entre señores y demás perceptores de rentas feudales, incluido el Estado, y los campesinos. La protesta de estos, cada vez mayor, habría terminado con la supresión de los derechos feudales o de la servidumbre, tal y como habría sucedido en la Francia de 1789 o en la Rusia de 1861. Indudablemente, los efectos de una presión fiscal y señorial sobre el equilibrio agrosilvopastoril no tenían que ser relevantes; pero si tenemos en cuenta que nos encontramos en medio de una estructura de la propiedad desequilibrada y con una presión señorial ya de por sí alta, un incremento de las cargas fiscales obligaban a los campesinos a vender una parte mayor de su cosecha, empujándolos cada vez más al mercado. En cualquier caso, tanto el aumento de la producción, del consumo, de las relaciones comerciales, de la renta o de los impuestos presionaban sobre una estructura jurídico-política pensada y diseñada para un mundo más o menos estacionario, donde las tensiones no eran muy intensas o se suavizaban de otra manera. La fuerza de la presión que ejercieran tales factores, junto con la capacidad del entramado jurídico-político feudal de resistirla, determinaría la necesidad de un cambio institucional.

Vamos a pasar revista a cada uno de los factores señalados en sus diversas manifestaciones o aspectos. En los ámbitos industrial, comercial y manufacturero no pueden encontrarse contradicciones serias con el Antiguo Régimen; más bien pudiera pensarse lo contrario, al menos en lo que la comercio americano y el mantenimiento del monopolio español se refiere. Las escasas experiencias industriales habidas no provocaron demandas energéticas ni de materias primas de la envergadura suficiente como para poner en cuestión las regulaciones mercantiles existentes y exigir una ampliación sustancial de los intercambios, o suprimir el sistema tributario tradicional ${ }^{26}$. Esa necesidad surgió de otros problemas más graves y profundos, derivados de la propia capacidad de la sociedad del Antiguo Régimen de garantizar la alimentación de sus individuos.

En efecto, la población del Reino de Granada creció de manera significativa a lo largo del siglo XVIII. Los datos que poseemos para Andalucía en su con-

25. Vid. las posiciones contenidas en el famoso "debate Brenner", en T.H. ASTON Y C.H.E. PHILPIN (Eds.), El debate Brenner. Estructura de clases agraria y desarrollo económico en la Europa preindustrial. Barcelona, 1988.

26. Ello no es incompatible con el hecho de que determinadas experiencias de crecimiento industrial se vieran finalmente abortadas por falta de combustibles. Ya hemos citado el caso de las fábricas de azúcar en Motril, pero podríamos citar también el caso de las farrerías guipuzcoanas. Según Monserrat Gárate, a finales del XVIII y comienzos del XIX comezó su estancamiento y posterior regresión. Las causas de la decadencia deben buscarse en al falta de madera y el subsiguiente encarecimiento de este combustible, provocada por el agotamiento de los bosques, excesivamente talados durante el siglo XVIII para roturar. Todo ello provocó un incremento del precio del hierro y una disminución de la demanda. M. GÁRATE, El proceso de desarrollo económico en Guipúzcoa. Bilbao, 1998. 
junto ${ }^{27}$ hablaban de un crecimiento del $0,65 \%$ anual. Como es de suponer, dicho crecimiento se concentró en el reino de Sevilla y en menor medida en el de Granada, en tanto que los de Jaén y Córdoba permanecieron prácticamente estancados. Ello se explica por la envergadura de las actividades económicas, especialmente comerciales que se llevaban a cabo desde ambos reinos, especialmente las referidas al tráfico colonial. No obstante, el crecimiento se moderó considerablemente en el reino sevillano, en tanto que la población granadina incrementó sus efectivos entre 1752 y 1797 en un porcentaje superior (27\%) al registrado en el período 1717-1752. En cualquier caso, parece que en conjunto la población granadina experimentó un crecimiento de un 55\% desde 1717 y hasta finales de siglo, crecimiento que debe considerarse bastante notable para la época, en magnitudes parecidas a las de Inglaterra. Sin duda, las posibilidades de incrementar aún las tierras irrigadas con pequeñas obras ${ }^{28}$ y la inusitada expansión hasta entonces que adquirieron cultivos industriales como el lino y el cáñamo o la caña de azúcar en las vegas granadinas, tanto de la costa como del interior, explican en parte este fenómeno de continuado crecimiento de la población en un período que en otros lugares fue más débil. No obstante, este hubiera sido mayor de no haber actuado como factores limitantes tanto las frecuentes crisis de mortalidad como las crisis de subsistencia. Con unos $20 \mathrm{hab} / \mathrm{km}^{2}$ aproximadamente, su densidad llegó a ser muy similar a la media española, pero muy inferior a la que entonces tenía Galicia, Madrid, País Vasco o Cataluña que duplicaban el número de habitantes por $\mathrm{km}^{2}$. Ello indica que o bien existía una abundancia relativa de tierras o bien estaba apropiadas de tal manera y producían tan poco que no admitían un asentamiento de población mayor. Frente a la concentración de la población andaluza en grandes núcleos, la población granadina se nucleaba en torno a una apreciable cantidad de pequeños pueblos y aldeas rurales, especialmente en la actual provincia de Granada.

En cualquier caso, la población granadina había aumentado en un siglo poco más de un 50\%. Conviene saber, pues cómo estaba organizada la producción agraria y el abastecimiento de granos básicos para la población para ver si la estructura jurídico-política de la sociedad feudal pudo absorber dicho crecimiento sin ponerse en riesgo o, si por el contrario, los reajustes necesarios acabaron dando al traste con ella, lo que equivale a decir que acabaron rompiendo el equilibrio agrosilvopastoril en que se había basado este tipo de sociedad y economía estacionarias. Dada la escasez estructural de nutrientes que hemos visto en epígrafes anteriores, los rendimientos por unidad de

27. Vid. el epígrafe referido a la población andaluza, debido a Julio Pérez Serrano en M. GONZÁLEZ DE MOLINA Y M. GÓMEZ OLIVER (Coords.), Historia de Andalucía Contemporánea (nuevos contenidos para su estudio). Granada, 2000, capítulo 11.

28. Vid. al respecto L. C. NAVARRO, Transformaciones agrarias liberales, pp. 147, quien califica el crecimiento demográfico de la actual provincia de Almería de "extraordinario" y lo asocia con la ampliación del regadío. 
superficie estaban estancados, de manera que sólo existían dos maneras seguras de aumentar el volumen de la producción: aumentando la cantidad de tierras cultivadas o poniendo en riego las ya existentes o consolidando en lo posible su dotación de agua. De esta época arranca el proceso de conversión de tierras de riego eventual en riego constante, que caracterizaría la historia de los regadíos granadinos. Ello contrasta, sin embargo, con la inexistencia de obras hidráulicas de cierta envergadura, a pesar de que el Despotismo llustrado se nos ha mostrado siempre como una época de grandes obras públicas. Como han puesto de manifiesto ya algunos autores que han cuestionado el mito ilustrado, los gobernantes de la época proyectaron y legislaron mucho, pero su escaso empeño por reformar realmente las estructuras feudales privaron al Estado de los necesarios recursos para financiar tanto proyecto. La única iniciativa digna de mención fue el intento fallido de construcción del Canal de Huéscar o de Carlos III, que debía transportar aguas de los ríos Guardal y Castril para regar tierras murcianas. Todavía puede contemplarse el "acueducto de las Animas", parte del mencionado canal, como testimonio del fracaso ilustrado y más tarde liberal.

Los trabajos de que disponemos registran un incremento del área regada que buscaba un mejor abastecimiento en productos básicos (aceite, vino y aguardiente y granos) y cierta diversificación de cultivos amparada en la demanda provocada por la inserción progresiva en los raquíticos circuitos comerciales de la época. El regadío proporcionaba un volumen de producción considerablemente mayor y su productividad aumentaba considerablemente respecto del secano. La ampliación subsiguiente, realizada a base de pequeñas obras hidráulicas, permitió que se produjera en la Vega de Granada y en una época temprana una "revolución agrícola" de parecida envergadura a la ocurrida poco antes en Inglaterra. Tanto el lino como el cáñamo no eran nuevos en las vegas, se cultivaban ya desde comienzos del siglo XVII, e incluso existen noticias en los tratadistas árabes sobre su inclusión dentro de rotaciones bastante complejas. El factor desencadenante de su expansión fue el deseo de la Secretaría de Marina de, practicando una política mercantilista, asegurarse el suministro de materia prima para los talleres de confección de lonas y cordelería para la marina española; muchos de estos talleres se establecieron en Granada, precedidos por un primer y breve intento de fabricación al por mayor con la creación de la Real Compañía de Granada. El crecimiento de la demanda de hilazas para los talleres textiles cordobeses, beneficiados por la buena coyuntura colonial, incrementó las buenas perspectivas para estas dos plantas industriales. Las exenciones fiscales concedidas a lo talleres de lino y cáñamo en 1778 y la obligación establecida en 1783 de utilizar materias primas de las Vegas de Granada y Levante en la fabricación de cordelaje y velámenes, provocaron un incremento muy importante de los precios pagados a los agricultores por ambas plantas. Esta fue la razón se su rápida expansión por la Vega granadina. Según Sanz Sam- 
pelayo ${ }^{29}$, el cultivo del lino se triplicó y el del cáñamo se multiplicó por seis, llegando a ocupar más de una cuarta parte de las tierras irrigadas de la Vega. A finales de siglo y según el Censo de Frutos y Manufacturas, existían en Granada 4811 obradores de lino y cáñamo que ocupaban a más de 5000 trabajadores.

El crecimiento de las áreas regadas se han documentado también en varias comarcas almerienses, la comarca de Baza y en el valle de Lecrín, por lo que no es descabellado pensar que este fenómeno fue común a todas aquellas zonas granadinas con posibilidades ${ }^{30}$. No obstante, los incrementos fueron bastante modestos. La orientación productiva de los regadíos seguía dominada, a pesar de todo, por cultivos cerealícolas, esencialmente trigo. En ello influyó seguramente el creciente déficit de granos básicos que sufrió Andalucía y el continuado ascenso que experimentaba su precio, tal y como veremos dentro de un momento. Mención aparte merece el maíz, introducido durante el siglo XVII, que comenzaría a expandirse en este período como segunda cosecha, especialmente en la vega de Motril y asociado, claro está, a los regadíos constantes, habida cuenta de sus altos requerimientos hídricos. En cambio, la producción tradicional de caña de azúcar, tras un auge espectacular, entraría en una situación de estancamiento, no logrando sobrepasar las cuatro mil toneladas que se habían alcanzado en $1800^{31}$. Ya comentamos anteriormente que la falta de combustibles y de fertilizantes orgánicos hizo muy difícil el incremento de los rendimientos, la ampliación de las superficies cañeras y, por tanto, la competencia con el azúcar que venía de América.

Pero como consecuencia del tipo de energía utilizada -renovable de origen solar- y de la potencia que ella permitía, las zonas regadas quedaron limitadas al alcance por gravedad de las aguas derivadas de los ríos y arroyos y el aporte de los acuíferos fue mínimo (afloramientos o pequeños pozos). Este tipo de tecnología, que se mantendría prácticamente hasta el siglo XX, y el intenso y amplio estiaje de los ríos granadinos, determinó el carácter precario de la mayor parte de las zonas regadas y la escasez estructural de agua disponible en verano incluso en los riegos constantes. Ello tuvo consecuencias muy importantes: se desarrollaron técnicas de ahorro y utilización del agua con el fin de asegurarse el abastecimiento; limitó la expansión de los cultivos intensivos o de los de ciclo veraniego -dado su alto consumo estacional-y fomentó la utilización de rotaciones que pretendían optimizar los recursos (combinando cultivos de altas exigencias hídricas con cultivos de bajo consumo en un mismo pago durante la misma campaña agrícola; v.gr.: lino-cáñamo/ habas-trigo-cebada); en definitiva, la dependencia de los condicionamientos ambientales, incrementa-

29. J, SANZ SAMPELAYO, Granada en el siglo XVIII. Garanada, 1980.

30. AL-MUDAYNA, Historia de los regadíos en España. Madrid, 1991.

31. A. GÁMEZ AMAIÁN, Transformaciones económicas y sociales en el Reino de Granada. Málaga, 1986. 
dos por una tecnología que traducía energía en trabajo de forma no intensiva, frenó la expansión de los regadíos y la mejora de sus dotaciones hídricas. Los incrementos de la producción producidos por esta vías tenían que ser forzosamente limitados.

La otra vía de aumento significativo de la producción se encontraba en la roturación de terrenos incultos o dedicados al aprovechamiento ganadero. Existen evidencias más que sobradas de la ampliación de las superficies cultivadas. Tanto Felipa Sánchez Salazari2, Manuel Martínez Martín ${ }^{33}$, como el propio Díaz López dan ejemplos muy significativos. Todos coinciden en que las roturaciones ilegales o los arrendamientos a censo efectuados por los Ayuntamientos fueron más frecuentes que las roturaciones autorizadas, e incluso llegaron a establecerse nuevos asentamientos campesinos al amparo de las leyes ilustradas de 1766$70^{34}$. Pero, pese a la multitud de ejemplos, las roturaciones en conjunto no debieron ser muy importantes superficialmente hablando a tenor de los datos más agregados que ofrece A. M Bernal ${ }^{35}$ para toda Andalucía y, sobre todo Amparo Ferrer $^{36}$, en un reciente trabajo referido a la provincia de Granada. El primero, basándose en cálculos indirectos sitúa el crecimiento de las superficies cultivadas entre la mitad del siglo XVIII y la mitad del XIX en un modestísimo 5\%, en tanto que Ferrer, utilizando datos más fiables, evalúa el dicho crecimiento en tan sólo el 3\%. Ello podría ser debido, como ocurrió en Andalucía en su conjunto a la baja presión de la población sobre la tierra, cuestión que parece sólo parcialmente predicable para el caso granadino, tal y como vimos. Más lógico es pensar en la fortaleza del régimen de amortización $y$, en general, del régimen jurídico que protegía la tierra. Ello no es incompatible, sino todo lo contrario como veremos, con el interés de determinados grupos sociales, privilegiados o no, en remover el régimen de amortización y aumentar el número de fincas rústicas que circulaban por el exiguo mercado de la tierra granadino. En este sentido, la crítica ilustrada al régimen de amortización, que hacía hincapié en la despoblación, en la falta de brazos para la agricultura y en la, por otro lado falsa, idea de que las "manos muertas" dejaban sin cultivar o cultivaban deficientemente la tierra, era interesada. Como demostramos en su día, muchos se sus argumentos, especialmente los referidos a las manos muertas, no eran del todo fundados ${ }^{37}$.

32. F. SÁNCHEZ SALAZAR, "Demanda de tierras para roturar en España durante el siglo XVIII", Agricultura y Sociedad, no 49, pp. 393-465

33. M. MARTÍNEZ MARTíN, Revolución Liberal y cambio agrario en la Alta Andalucía, Granada, 1996.

34. Vid la tesis doctoral de M. FERNÁNDEZ, De apropiaciones y privatizaciones: el patrimonio territorial del concejo de Antequera (siglos XV-XIX). Málaga, 1998.

35. A.M. BERNAL, Historia de Andalucía. Barcelona, 1981, tomo VII.

36. A. FERRER RODRÍGUEZ, "La producción agraria", en M. TITOS (dir.), Historia Económica de Granada. Granada, 1998.

37. M. GONZÁLEZ DE MOLINA, desamortización, deuda pública y crecimiento económico. Andalucía, 1820-1823. Granada, 1985, capítulo III. 
En cualquier caso, la cantidad de tierras sometidas al régimen de amortización parece, muy importante, especialmente si la medimos en términos porcentuales respecto al conjunto de la renta agraria: las más ricas o mejor dotadas territorialmente estaban bajo propiedad de la nobleza, ricos vinculistas y más frecuentemente la Iglesia. Lo mismo podríamos decir de la enorme "reserva de tierras cultivables" que mantenían bajo titularidad comunal o patrimonial, y por tanto no enajenables, los concejos y villas diseminadas por todo el Reino. Por otro lado, parece haber coincidencia entre los historiadores en el pobre resultado que las medidas ilustradas tuvieron en este terreno, al menos hasta que no se tuvo más remedio que plantear la primera medida desamortizadora generalizada en 1798. Como dice Pedro Ruiz Torres, "las reformas políticas de los ministros ilustrados, Ilevadas a cabo en una coyuntura de crisis del antiguo régimen que se hizo patente en la segunda mitad del siglo XVIII, estaban lejos de pretender destruir los dos pilares fundamentales del dominio de la nobleza y del clero: el señorío y la propiedad vinculada. A la burocracia real le interesaba contener la expansión de ambos y en sus planes no entraba una política antiseñorial o que estuviese encaminada a la completa liberalización de la propiedad. Junto al reconocimiento y la extensión de la autoridad real, la preocupación que mantuvieron por hacer rentables económicamente los viejos dominios de los señores, muestra claramente el conservadurismo social de la reforma promovida por la burocracia absolutista... el reformismo ilustrado hizo muy poco en favor de la liberalización de la propiedad y dejó intactos los fundamentos jurídicos del viejo sistema" ${ }^{138}$. En definitiva, la posibilidad de aumentar significativamente la producción, ampliando la superficie cultivada, estaban también limitados.

Se ha constatado un aumento significativo de los mismos durante la primera mitad del siglo XVIII y un aumento mucho más modesto, próximo al estancamiento, durante la segunda mitad, pero con fuertes fluctuaciones interanuales. Tales fluctuaciones eran producto del régimen de precipitaciones propio del Reino de Granada, del que dependía estrechamente como vimos la entidad de las cosechas, y estaban en la base, aunque no los explican, de los problemas de abastecimiento alimentario de los que luego hablaremos. En otros términos, parece que el crecimiento de las superficies cultivadas y la expansión modesta del regadío no dieron lugar a un aumento sustantivo de la producción de granos básicos. En este sentido, tanto la expansión del regadío por casi todo el Reino como la expansión de las tierras cultivadas en las zonas costeras, no debieron aumentar las disponibilidades de granos per capita, sino todo lo contrario: la expansión de la vid y de los cultivos industriales se hizo en detrimento del cereal. En cualquier caso, nos movemos aún en el terreno de las conjeturas. La frecuente demanda de nuevas tierras para rroturar y la importa-

38. P. RUIZ TORRES, "Señoríos y propiedad en la crisis del Antiguo Régimen", en S. de DIOS y Otros (Eds..), Historia de la propiedad en España, siglos XV-XX. Madrid, 1999, pp. 332. 
ción de trigo parecen avalar la tesis de una carencia estructural de granos básicos, pero no existen datos concluyentes al respecto. Si damos crédito a los datos de producción de trigo para 1791, estimados por Gonzalo Anes ${ }^{39}$ a partir de la renta decimal en las distintas diócesis del Reino de Granada, y los dividimos por la población existente por entonces, se obtiene una disponibilidad per capita de trigo muy baja, de poco más de $65 \mathrm{~kg}$ por año. No obstante, la autosuficiencia se lograría sólo décadas más tarde, sin haberse producido cambios sustanciales en los principales indicadores agrarios, pese a estar ya en plena sociedad liberal. En cualquier caso, la producción no debió superar al crecimiento de la población y ello, junto con las oscilaciones interanuales, debió crear un contexto favorable al surgimiento de un fenómeno de escasez social, en el que la distribución de la renta agraria y el funcionamiento de los mercados tuvo una participación decisiva.

Pero veamos cómo se producía tal escasez, dependiente de la configuración específica de las relaciones sociales del Antiguo Régimen y, por tanto, socialmente construida. La imposibilidad de absorber el crecimiento de la población sin cambiar más que muy tímidamente el régimen jurídico de la propiedad, tenía que producir necesariamente problemas de abastecimiento alimentario entre la población, a no ser que se suplieran con el recurso a importaciones desde fuera del Reino. Pero ello no era nada fácil, dada la escasez de los intercambios comerciales y a su carácter periférico a los grandes núcleos de población rural. Los altísimos costes de transporte en el interior del Reino de Granada, encarecían de tal manera las mercancías -entre ellas los granos- que desanimaban su circulación y reducían su uso a momentos de especial carestía o malas $\operatorname{cosechas~}^{40}$. A ello deben añadirse los frecuentes derechos de tránsito más el pago de alcabalas. Todo ello obligaba a cada pueblo o cada comarca, que no estuviese plenamente integrada en los raquíticos circuitos comerciales, a dedicar grandes cantidades de tierra al cultivo de cereales, en la medida en que el ganado de labor y los propios labradores tenían en la cebada y en el trigo su principal fuente de aprovisionamiento energético. Por otro lado, el escaso giro de las actividades comerciales en el interior se veían agudizado por la mala distribución del producto agrario y, paradójicamente, por la concurrencia

39. G. ANES, Las crisis agrarias en la España Moderna. Madrid, 1970, p. 149.

40. Un folleto anónimo, escrito en 1814, reflejaba la desarticulación del mercado interno de la siguiente forma: "Lo mismo puede observarse en otras provincias; aún respecto de aqueIlos frutos, cuyos portes de unas a otras influyen muy poco en el precio. En Granada se computa el aceite a 80 reales la arroba, en las provincias confinantes de Jaén y Sevilla a 30: el vino a 20 en Guadalaxara y sólo a 8 en Madrid: el vinagre a 9 en Córdoba, y en su contigua Extremadura a 49: la cera a 90 en Granada y a 250 en Murcia confinante: a 80 en Iviza, y a 375 en Guadalaxara: la seda fina a 40 en Cuenca, a 100 en Guadalaxara, y a 160 en la Mancha ambas contiguas: la lana fina a 60 en Sevilla, y a 200 la ordinaria en Mallorca... y de este tenor en otras provincias y artículos". Vicios de la Contribución Directa decretada por las Cortes Extraordinarias en 13 de Septiembre de 1813. Madrid (imprenta Ibarra), 1814, p. 28. 
de los mayores perceptores de rentas al mercado. En efecto, en otras partes de este volumen se ha descrito el reparto tan desigual de la propiedad de la tierra. En tanto que principal condición de la producción agraria, la posesión de derechos o dominio sobre ella condicionaba sobremanera la distribución de la riqueza. Pero la renta de la tierra no constituía la única forma de captación del producto agrario. Un conjunto de rentas y derechos, entre los que destacaba el diezmo, obligaban a los campesinos y demás productores a prescindir de una parte importante de las cosechas que iba a parar al mercado.

Parece claro que en una economía estacionaria en la que una parte sustancial de la producción iba al autoconsumo, el excedente comercializable dependía de la entidad de la renta en sus diversas modalidades (diezmo, prebendas y monopolios, rentas de la tierra, derechos señoriales e impuestos, ya fuera en especie o en metálico) ${ }^{41}$, obligando a lanzar al mercado un porcentaje importante del producto bruto agrario sin posibilidad de ser autoconsumido o abastecer las necesidades locales. Porcentaje que buscaba el precio más alto y, por tanto, era propenso a la acaparación y el almacenamiento, a enviarlo a otras provincias o al exterior, especialmente a América. No cabe duda que las frecuentes extracciones de trigo con destino a las colonias agravaron el desabastecimiento interno. Según Gonzalo $\mathrm{Anes}^{42}$, tales extracciones se hicieron más frecuentes tras el establecimiento de la libertad de comercio en Octubre de $1765^{43}$. La renta de la tierra junto con las demás rentas en metálico, mantuvieron su tendencia al alza, persiguiendo de cerca los precios de los granos, tal y como ha demostrado Gonzalo Anes ${ }^{44}$. Parece lógico pensar que una parte creciente del producto bruto tuvo que venderse en el mercado para hacer frente al pago de tales rentas en perjuicio de su capacidad de autoconsumo. Esas circunstancias tenían necesariamente que agravar el desabastecimiento que solía producirse en épocas de malas cosechas, provocando hambrunas y crisis de subsistencias, e incluso es razonable pensar -a tenor de la frecuencia de las

41. Según Anes, a comienzos del siglo XIX se calculaba que el diezmo eclesiástico absorbía más del $50 \%$ del producto neto de la agricultura y que de diez partes de trigo comercializado, nueve procedían de los perceptores de derechos señoriales, de rentas y de diezmos. El mismo autor recoge un informe del corregidor de Soria en el que se afirmaba que entre comerciantes, poseedores de tierras, diezmos y excusado, se retenía, al menos la mitad de la cosecha. Cf. G. ANES ÁLVAREZ, Las crisis agrarias..., pp. 275- 276, 301.

42. G. ANES ÁLVAREZ, Las crisis agrarias.... p. 274.

43. "Aunque históricamente siempre habían existido problemas de escasez de trigo, sería a raíz de la promulgación de la Pragmática de 11 de Julio de 1765, en la que se liberalizaba el comercio y se abolía la tasa de precios máximos y mínimos del trigo, cuando estos problemas se agudizarían al no ir acompañadas estas medidas de otras que agilizaran el tráfico y garantizaran el aprovisionamiento regular de todos los rincones de la Monarquía. En estas circunstancias, lejos de dejar paso a la libre competencia como elemento regulador de precios, se abrió la puerta a la especulación". J.E NIEVES CARRASCOSA, La Desvinculación de la propiedad en la comarca de jaén durante la primera mitad del siglo XIX, 1798-1845. Jaén, 1991, p. 57.

44. G. ANES ÁLVAREZ, Las crisis agrarias en la España Moderna. Madrid, 1970. 
quejas de arbitristas y autoridades municipales- que acabaron convirtiendo el desabastecimiento en una situación demasiado frecuente.

El alza de las rentas, el desabastecimiento periódico, la escasez de tierras en arrendamiento y en el encarecimiento de las subsistencias, que alcanzaron su máximo a finales del siglo XVIII y comienzos del XIX, especialmente tras la crisis de 1804-5, fueron manifestaciones evidentes de la crisis profunda que atravesaba una sociedad incapaz de dar soluciones estables a estos problemas que afectaban sobre todo a los grupos sociales más desfavorecidos, a la vez los más numerosos. Más adelante veremos cómo se tradujo el descontento campesino frente a estas adversas condiciones de existencia. Varias podían ser las soluciones a todo este conjunto de tensiones estructurales: una mejora de las comunicaciones y la práctica desaparición del sistema impositivo del Antiguo Régimen -lo que equivalía a una reforma fiscal en profundidad- o permitir nuevas roturaciones que incrementaran la producción bruta, lo que tropezaba con la especialización ganadera de la Corona de Castilla, los privilegios de la Mesta y el régimen jurídico comunal, municipal o real de los baldíos; es decir, con el régimen de amortización. Serían precisamente estas dos campos -reforma fiscal y de la propiedad- donde se ensayaran tímidamente algunas medidas que, como hemos visto, fueron insuficientes. Precisamente en su necesidad convergían grupos cada vez más importantes de la nobleza y de la élites locales no tituladas, agobiados por la estrechez del mercado de tierras y la imposibilidad de incrementar la cuantía de las rentas, cosa que sólo podía conseguirse mediante incrementos patrimoniales, habida cuenta de la práctica imposibilidad de mejorar los rendimientos por unidad de superficie. Pero las cosas podían haber continuado como estaban, recurriendo a pequeñas reformas, de no haber mediado otras circunstancias desencadenantes del definitivo derrumbe del Antiguo Régimen.

\section{Los factores desencadenantes de la crisis}

Las tensiones estructurales que en el Reino de Granada hicieron posible la crisis y el desmoronamiento (que no derribo) del Antiguo Régimen tienen más que ver con los problemas de abastecimiento alimentario y la obsolescencia del régimen de amortización que con el peso directo de los derechos señoriales y la contestación campesina o las contradicciones insalvables entre la burguesía y sus actividades comerciales o industriales y la estructura jurídico-económica del Antiguo Régimen, tal y como ocurrió en Francia. Así pues, el Antiguo Régimen no fue derribado por el empuje del "estado llano", sino que se "derrumbó", herido de muerte por sus propias incapacidades. Pese a la gravedad de la crisis, hubo que esperar a la aparición de circunstancias más coyunturales e, incluso, algunas de índole externa como la invasión francesa, para que la Revolución Liberal sucediese al derrumbe del Antiguo Régimen. La Revolución Liberal no fue, al menos en el Reino de Granada, una necesidad histórica derivada de la propia crisis. 
No han surgido nuevos datos que hagan modificar las tesis que hemos mantenido en trabajos anteriores, respecto de los factores que precipitaron la caída del Antiguo Régimen. Durante el siglo XVIII, especialmente en su segunda mitad, tuvo lugar como hemos visto un significativo proceso de acumulación de recursos, tanto en la tierra -al calor del alza de la renta y de los precios- como en el sector comercial con el tráfico sobre todo colonial; la colocación rentable de estos recursos resultó cada vez más difícil cuando el mercado americano comenzó a sufrir dificultades serias y la crisis financiera del estado desalentó los préstamos a la Real hacienda como fórmula de inversión alternativa. La orientación hacia los bienes inmobiliarios pareció la mejor salida en el contexto de una inflación difícilmente controlable. El precio de la tierra y de las viviendas, fruto de una demanda intensa, llegó a superar al crecimiento de la renta, de los alquileres y de los precios agrícolas. Los ilustrados denunciaron repetidamente esta circunstancia ${ }^{45}$. De esta manera se produjo la confluencia de sectores sociales diferentes en la inviabilidad del mayorazgo y del sistema de vinculación como sistema indispensable para la organización de la reproducción social. Recuérdese que el incremento de los ingresos para aquellos que poseían capital difícilmente podía conseguirse mediante una intensificación significativa de la producción agraria. Como vimos, ésta estaba ambiental y tecnológicamente limitada y la manera más factible de aumentar la cuantía de las rentas percibidas era mediante aumentos patrimoniales; es decir, mediante la adquisición de más tierra. Es por ello que el precio de esta sufrió, pese a tener cada vez menos que ver con la renta que proporcionaba y haberse producido un incremento apreciable de las compraventas, una subida muy importante.

En ese contexto el sistema de amortización resultó insostenible y, como culminación de una política ilustrada restrictiva, se ensayó con éxito la desamortización de una parte del patrimonio propio o administrado por la Iglesia. La llamada "Desamortización de Godoy", que hemos estudiado en otra parte ${ }^{46}$, significó la enajenación a manos privadas sin posibilidad de vinculación de 5.209 fincas en el Reino de Granada, por un valor de 73.556.522 reales. La cotización de los bienes puestos a subasta y sus altos precios de salida, cuyas rentas ape-

45. "No obstante los fondos empleados en tierras no dan entre nosotros mayores intereses que los demás; lo cual depende principalmente de que los mayorazgos y manos muertas tienen fuera del comercio una cantidad considerable de tierra que vender que capitales que emplear en ellas; de modo que estas ventas se hacen al precio de monopolio impidiéndose así el aumento de la Agricultura, pues se ocuparon por esta causa en otros giros muchos capitales que contribuían a él, y sin los cuales es imposible lograrlo". V ALCALÁ GALIANO, Sobre la necesidad y justicia de los tributos, fondos donde deben sacarse y medios de recaudarlos. Tomo IV de las Actas de la Sociedad Económica de Segovia. Segovia, s.a.

46. M. GÓMEZ OLIVER y M. GONZÁLEZ DE MOLINA, "Crisis fiscal y quiebra del Antiguo Régimen. Los resultados de la Desamortización de Godoy en Andalucía", en M. PÉREZ LEDESMA y J. DONÉZAR (eds.), Antiguo Régimen y Liberalismo: homenaje a Miguel Artola. Madrid, 1995. 
nas llegaban al 3\% de su valor en venta, son suficientemente expresivos de los efectos que aún producía el régimen de amortización.

La Guerra de la Independencia, la pérdida definitiva de los mercados coloniales, el agravamiento de la crisis financiera y fiscal del Estado y la crisis económica que tuvo lugar inmediatamente después del conflicto, con sus consecuencias en la caída de los precios y rentas agrarias y el aumento de la presión tributaria que ello trajo consigo, fueron factores que abocaron al cam$\mathrm{bio}^{47}$. Un cambio que evitara algo parecido a lo que ocurrido durante la primera república francesa, tan temida por los pudientes. En este sentido, la actitud pasiva del campesinado, negándose a pagar diezmos, rentas e impuestos en un contexto deflacionario y de desabastecimiento alimentario supuso un importante quebranto para la economías nobiliarias y eclesiásticas y en general para todos los perceptores de rentas. Este fenómeno no ha sido suficientemente valorado en cuanto a su importancia en el desencadenamiento de la Revolución Liberal, quizá porque carezcamos de estudios específicos al contrario de lo que ocurre en otros lugares de la península. La actitud más activa del campesinado durante la Guerra de la Independencia sólo mereció el apunte de algún contemporáneo en medio de tanto fervor "nacionalista"; pero ambas actitudes condujeron a una "crisis de hegemonía" de unos grupos dominantes a los que hasta entonces nadie había sido capaz de cuestionar.

Debían tomarse, pues, un conjunto de medidas que hicieran posible remontar la crisis con el menor coste posible. Lo esencial consistía en promover el crecimiento de la producción agraria y asegurar por esa vía tanto el abastecimiento como el crecimiento de las rentas, cuestión que sólo podía tener lugar mediante la abolición de régimen de amortización, la reforma del sistema tributario y todo lo que "se opusiera a la libertad económica y al desarrollo del interés individual". La revolución estaba en marcha.

47. He desarrollado ampliamente la coyuntura económica y hacendística posterior a 1808 en M. GONZÁLEZ DE MOLINA, Desamortización, deuda pública y crecimiento económico. Andalucía, 1820-1823. Granada, 1985. 